\title{
Status Dystonicus: A Rare Presentation of Molybdenum Cofactor Deficiency
}

\author{
Kursat Bora Carman ${ }^{\mathrm{a}, \mathrm{d}}$, Gonca Kilic Yildirim ${ }^{\mathrm{b}}$, Eylem Kiral ${ }^{\mathrm{c}}$, Ozan Kocak ${ }^{\mathrm{a}}$, \\ Sibel Lacinel Gurlevik ${ }^{\mathrm{a}}$, Coskun Yarara ${ }^{\mathrm{a}}$, Ener Cagri Dinleyicic, \\ Sultan Durmus Aydogdu ${ }^{\mathrm{b}}$
}

\begin{abstract}
Molybdenum cofactor deficiency (MOCOD) is a severe inborn error of metabolism. It is characterized by neonatal presentation of intractable seizures, feeding difficulties, severe developmental delay, microcephaly with brain atrophy and coarse facial features. Movement disorders have been rarely reported as presenting complaint of MOCOD. We report a previously healthy 10 months old boy presenting with acute onset status dystonicus. A novel homozygote IVS1$1 \mathrm{G}>\mathrm{A}(\mathrm{c} .251-1 \mathrm{G}>\mathrm{A})$ mutation was determined and he was diagnosed as MOCOD. MOCOD must be considered in the differential diagnosis of movement disorders.
\end{abstract}

Keywords: Status dystonicus; Children; Molybdenum cofactor; Metabolism

\section{Introduction}

Molybdenum cofactor deficiency (MOCOD, OMIM: 252150) is a rare autosomal recessive neurometabolic disease $[1,2]$. The functions of three enzymes, sulfite oxidase, xanthine dehydrogenase and aldehyde oxidase altered. Patients typically present with neonatal seizure, severe neurodevelopmental delay, epileptic encephalopathy, lens dislocation, feeding difficulties and dysmorphias [3]. Movement disorders have been rarely reported as presenting complaint of MOCOD [4-6].

We report a child presenting with status dystonicus, who was diagnosed as MOCOD based on low level of serum uric acid and gene analysis.

Manuscript submitted October 30, 2017, accepted December 12, 2017

aDepartment of Pediatric Neurology, Eskisehir Osmangazi University Hospital, Eskisehir, Turkey

${ }^{b}$ Department of Pediatric Metabolic Diseases, Eskisehir Osmangazi University Hospital, Eskisehir, Turkey

${ }^{\mathrm{c}}$ Department of Pediatric Intensive Care, Eskisehir Osmangazi University Hospital, Eskisehir, Turkey

${ }^{\mathrm{d} C}$ Corresponding Author: Kursat Bora Carman, Department of Pediatric Neurology, Eskisehir Osmangazi University Hospital, Eskisehir, Turkey.

Email:kbcarman@gmail.com

doi: https://doi.org/10.14740/ijcp283w

\section{Case Report}

A 10-month-old boy referred to emergency unit because of sudden onset opisthotonic posture. He was the only child of non-consanguineous parents. The mother and father were 30 years old and 33 years old respectively and both are officers. There was no family history of genetic illness. His parents reported that he was previously healthy and had fever and cough for 2 days. No medication was used to treat those symptoms. On the day of presentation while he was playing with toys, he developed opisthotonos suddenly. He was born by cesarean section after a normal pregnancy at 38 weeks of gestation, and was the first child. His birth weight was 3,200 g. His developmental milestones were reported as appropriated to his age by parents. However previous medical reports of him could not be obtained to confirm that neurodevelopment of his was appropriate.

A physical and neurologic examination revealed a head circumference of $42 \mathrm{~cm}$, a height of $64 \mathrm{~cm}$, and a weight of $5,860 \mathrm{~g}$, all of which were at or below the 5th percentile for his age. He was on opisthotonic posture (Fig. 1a). He had general-

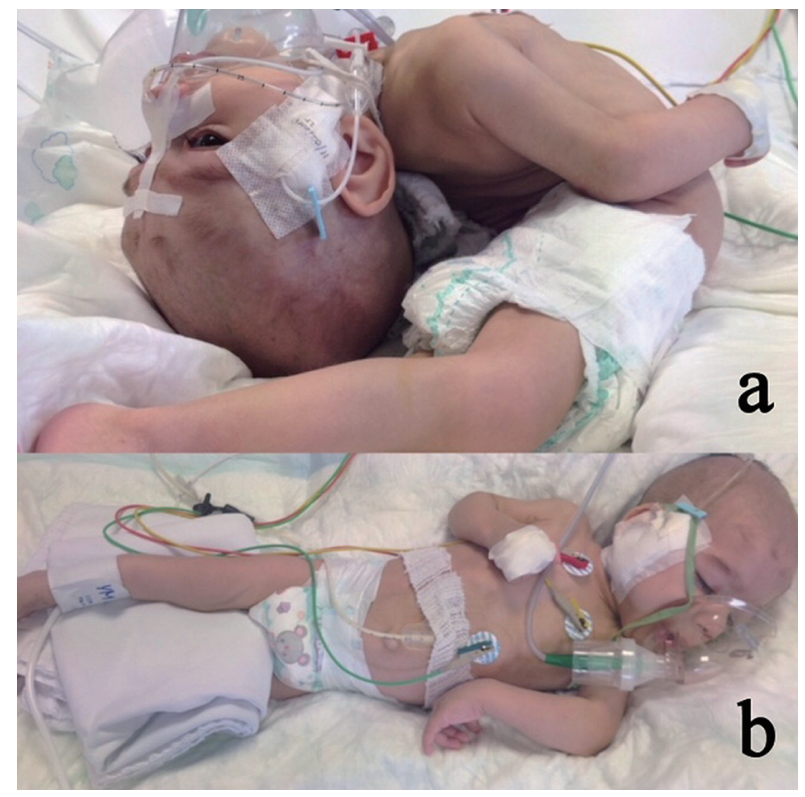

Figure 1. The posture of the patient before (a) and after the treatment (b). 


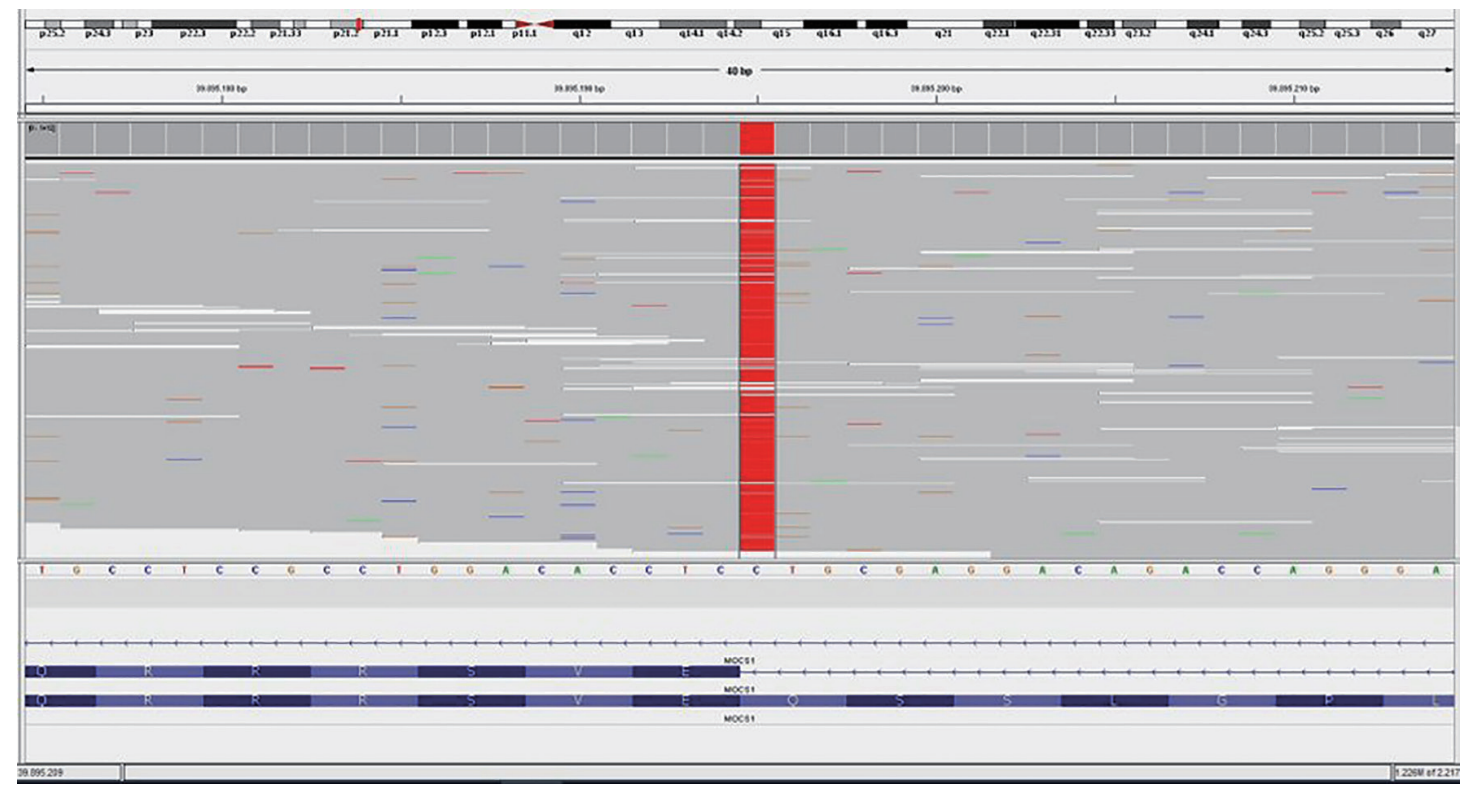

Figure 2. Illustration of DNA sequencing of patient.

ized increase in muscle tone. Deep tendon reflexes were hyperactive. Enteral feeding was impossible. He was hospitalized in intensive care unit and treatment with diazepam $(0.3 \mathrm{mg} /$ $\mathrm{kg}$ ) and baclofen $2 \times 2.5 \mathrm{mg}$ was started. No clinical response was observed. Midazolam infusion $(0.2 \mathrm{mg} / \mathrm{kg} / \mathrm{h})$ was added to the treatment. Because of unresponsiveness, the dose of baclofen was increased ( $4 \mathrm{mg} / \mathrm{kg} / \mathrm{d})$. Status dystonicus subsided and the patient was relaxed (Fig. 1b). The results of routine laboratory investigations of blood and urine involving serum lactate, pyruvate and ammonia, urine and plasma amino acids concentrations were all within normal limits except serum uric acid level $(0.3 \mathrm{mg} / \mathrm{dL})$. The repeated uric acid levels were also low. There was increased urinary excretion of sulfite (dipstick test positive). Brain magnetic resonance imaging showed corpus callosum atrophy, enlargement of lateral ventricular dilatation, and multicystic encephalomalacia. The results of ophthalmologic, echocardiographic, abdominal ultrasonographic examinations were all normal. Electroencephalography (EEG) revealed normal sleep pattern and no epileptiform discharges. To confirm, the MOCOD diagnosis, genetic analysis was performed. Sequencing MOCS1 gene revealed previously unreported homozygote IVS1-1G $>$ A (c.251-1G $>$ A) mutation in the sixth chromosome, p21.2 region (Fig. 2). He was discharged on oral baclofen treatment. The patient moved to another city and it was learned that he died 3 months later.

A written consent was received from the parents of the patient.

\section{Discussion}

In the patient described here, movement disorder "status dystonicus" was the presenting complaint of MOCOD. Movement disorders are rarely chief complaint of MOCOD. Ichida et al [4] reported a 7-year-old boy presenting with mental retarda- tion, dystonic movements and seizure. That patient has had also mutation on MOCS1 gene like our case. A 2-year-old boy presented with spastic quadriplegia who was previously misdiagnosed as cerebral palsy, and sequencing of the MOCS2A gene revealed heterozygosity for $(\mathrm{c} .265 \mathrm{~T}>\mathrm{C})+(266 \mathrm{~A}>\mathrm{G})$, which was diagnosed as MOCODB [5]. However, no phenotype genotype correlation is present. A 2-year-old patient was described presenting with spasticity and psychomotor retardation and a homozygous c.1739A $>\mathrm{C}$ transversion in exon 18 was reported.

MOCOD might present with parkinsonian features. Alkufri et al [6] reported an adult with progressive apathy, slowness of movements, tremor and generalized parkinsonism was reported by and diagnosed as MOCOD.

Status dystonicus is a life-threatening movement disorder emergency [7]. It is often a triggered event. The parents of our case reported that the patient was previously healthy and had fever and cough for 2 days and onset of status dystonicus was sudden. Infection, drugs, trauma, surgery, "metabolic disorder" decompensation, stress and pain might trigger status dystonicus $[8,9]$. It is possible that infection and fever were triggers of present case.

Many different drugs, used individually or in combination, can be used to treat status dystonicus including baclofen, benzodiazepines, L-3,4-dihydroxyphenylalanine (L-DOPA), tetrabenazine, benzhexol, choral hydrate, propofol, barbiturates, pimozide, haloperidol and anti-cholinergics with varying success rates. The non-responded patients may require more invasive treatments such as intrathecal baclofen, deep brain stimulation or neurosurgery [8-11]. The pediatric dose of oral baclofen is uncertain $[12,13]$. In our case, pharmacological therapy by baclofen was $(4 \mathrm{mg} / \mathrm{kg} /$ day) successful and our patient improved. There is no definitive treatment of MOCOD $[3,14]$. The present case was not followed and died within 3 months. 
In conclusion, the present case demonstrated that a patient with status dystonicus of underdetermined cause should undergo testing for uric acid in both serum and urine. Low serum uric acid level and genetic analysis may lead to a correct diagnosis of MOCOD.

\section{Conflict of Interest}

The authors declare no conflict of interest.

\section{Financial Support}

The authors declare no financial assistance.

\section{References}

1. Schwarz G, Mendel RR, Ribbe MW. Molybdenum cofactors, enzymes and pathways. Nature. 2009;460(7257):839847.

2. Duran M, Beemer FA, van de Heiden C, Korteland J, de Bree PK, Brink M, Wadman SK, et al. Combined deficiency of xanthine oxidase and sulphite oxidase: a defect of molybdenum metabolism or transport? J Inherit Metab Dis. 1978;1(4):175-178.

3. Atwal PS, Scaglia F. Molybdenum cofactor deficiency. Mol Genet Metab. 2016;117(1):1-4.

4. Ichida K, Aydin HI, Hosoyamada M, Kalkanoglu HS, Dursun A, Ohno I, Coskun T, et al. A Turkish case with molybdenum cofactor deficiency. Nucleosides Nucleotides Nucleic Acids. 2006;25(9-11):1087-1091.

5. Kikuchi K, Hamano S, Mochizuki H, Ichida K, Ida H. Molybdenum cofactor deficiency mimics cerebral palsy: differentiating factors for diagnosis. Pediatr Neurol. 2012;47(2):147-149.
6. Alkufri F, Harrower T, Rahman Y, Hughes E, Mundy H, Knibb JA, Moriarty J, et al. Molybdenum cofactor deficiency presenting with a parkinsonism-dystonia syndrome. Mov Disord. 2013;28(3):399-401.

7. Singer HS, Mink JW, Gilbert DL, Jankovic J. Dystonia. Movement disorders in childhood,1st ed. Philadelphia, Elsevier Saunders; 2010. p. 97-109.

8. Allen NM, Lin JP, Lynch T, King MD. Status dystonicus: a practice guide. Dev Med Child Neurol. 2014;56(2):105112.

9. Grosso S, Verrotti A, Messina M, Sacchini M, Balestri P. Management of status dystonicus in children. Cases report and review. Eur J Paediatr Neurol. 2012;16(4):390395.

10. Kyriagis M, Grattan-Smith P, Scheinberg A, Teo C, Nakaji N, Waugh M. Status dystonicus and HallervordenSpatz disease: treatment with intrathecal baclofen and pallidotomy. J Paediatr Child Health. 2004;40(5-6):322325.

11. Walcott BP, Nahed BV, Kahle KT, Duhaime AC, Sharma N, Eskandar EN. Deep brain stimulation for medically refractory life-threatening status dystonicus in children. J Neurosurg Pediatr. 2012;9(1):99-102.

12. Vaamonde J, Narbona J, Weiser R, Garcia MA, Brannan T, Obeso JA. Dystonic storms: a practical management problem. Clin Neuropharmacol. 1994;17(4):344-347.

13. He Y, Brunstrom-Hernandez JE, Thio LL, Lackey S, Gaebler-Spira D, Kuroda MM, Stashinko E, et al. Population pharmacokinetics of oral baclofen in pediatric patients with cerebral palsy. J Pediatr. 2014;164(5):1181-1188 e1188.

14. Schwahn BC, Van Spronsen FJ, Belaidi AA, Bowhay S, Christodoulou J, Derks TG, Hennermann JB, et al. Efficacy and safety of cyclic pyranopterin monophosphate substitution in severe molybdenum cofactor deficiency type A: a prospective cohort study. Lancet. 2015;386(10007):1955-1963. 